Hot prospect
$\begin{aligned} & \text { Patent loss opens way } \\ & \text { for cheaper PCR } \\ & \text { enzymes } \\ & \text { p622 }\end{aligned}$

\title{
Researchers unnerved by echoes of the past in Russian directive
}

Bryon MacWilliams, Moscow and David Adam, London

Foreign links with Russian science are secure - at least for the time being - despite last week's emergence of a directive from the Russian Academy of Sciences requiring all researchers' contacts with foreigners to be reported, in detail, to the academy.

Sergei Kovalyov, a member of parliament

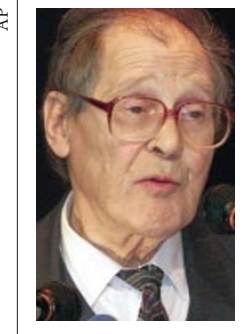
who made the contents of the directive public in a radio interview on 31 May, claimed that its existence reflected a revival of the state security apparatus of the Soviet era.

But researchers inside and outside Russia say the Sergei Kovalyov: directive need not dampen concerned over collaboration between the directive.

Russian and foreign scientists. Some of them cau-

tion, however, that its existence may reflect a trend towards less open scientific exchange under Russian President Vladimir Putin.

The directive instructs the academy's departments and its 440 research institutes to tighten controls on the foreign contacts of their 53,000 scientists — ostensibly to curtail the loss of state secrets through espionage.

Kovalyov, a noted human rights activist, says that the directive reflects the security outlook of Putin, a former KGB officer. "He who assumes power gets to choose the music. Members of the KGB have assumed power. They are doing that which they were taught to do," he says. After it was leaked, some observers, including the financier George Soros, who has supported extensive research efforts in Russia since the end of the Cold War, expressed alarm at its likely implications.

But Igor Milovidov, an assistant secretary of the academy, describes the directive as "an ordinary little reminder". And Eugene Sverdlov, director of the Institute of Molecular Genetics in Moscow, says: "I cannot see any threat to scientific freedom or the exchange of ideas in this. We received an instruction to indicate who we met during trips abroad from the academy maybe two years ago. Time has passed and nothing has happened. People still go abroad as freely as they did before."

Zhores Medvedev, an exiled Russian geneticist living in London, suggests the reason for the directive is bureaucratic. "I don't think this is a political move," he says. "It was necessary to establish certain kinds of rules because nobody was telling the academy what kind of grants they received from abroad."

But other Russian scientists suspect that the directive does represent an effort by the Russian Academy of Sciences to reassert some control over its staff. Maxim Frank-Kamenetskii, a biophysicist at Boston University, says: "I think this is an attempt by the leadership [of the Academy of Sciences] to regain some of the control it lost over recent years."

The directive comes at a time when several Russian civilians have been arrested on espionage charges. A researcher specializing in arms control is currently on trial for allegedly spying for unnamed NATO member countries, and a physicist is awaiting trial on suspicion of spying for China. "Trials linked to the so-called excessive freedom of scientific research are not so uncommon for us now," Kovalyov told the radio station.

The greatest impact of any clamp-down on foreign links will be on those academy institutes that have thrived since the 1991

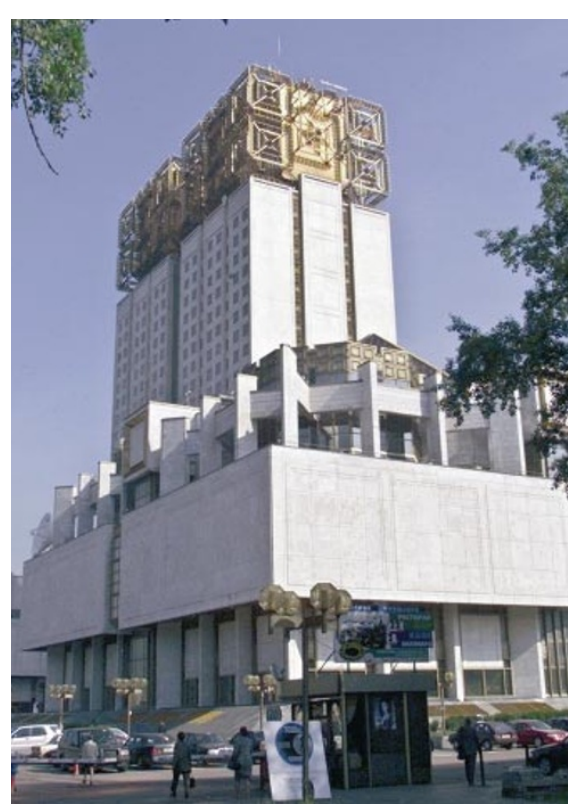

Control centre: the Russian Academy of Sciences is seeking tighter regulation of foreign contacts.

collapse of the Soviet Union. These have struck deals with foreign laboratories and businesses, and funds from abroad make up significant portions of their budgets.

\section{Watchdog fuels doubts over laser}

\section{Rex Dalton, San Diego}

A Congressional watchdog agency has strongly criticized the US Department of Energy (DOE) for the way it has managed the National Ignition Facility (NIF), the troubled laser fusion project being built at the Lawrence Livermore National Laboratory in California.

The General Accounting Office (GAO) issued a report on 1 June saying that NIF has not yet had a fully independent review of its costs and prospects for technical success. The agency adds that the DOE has not hired the necessary staff to manage the project, and that significant technical questions remain about NIF's likely contribution to the nuclear weapons 'stockpile stewardship' project, of which it is part.

NIF, a stadium-sized laser device that is supposed to ignite fusion in a tiny pellet of tritium-deuterium fuel, is now scheduled to be completed in 2008, six years later than planned, at a total cost of $\$ 4.2$ billion, or about $\$ 1.4$ billion over its initial budget.

James Anderson, the DOE's project officer for NIF, says the GAO report is generally fair, but takes issue with the need for an independent review. "We are satisfied NIF has been adequately reviewed," he says. He called the hiring of more scientific management staff for the project "a work in progress". 